\title{
Kinetics, Thermodynamics, and Isotherms of Methylene Blue Adsorption Study onto Cassava Stem Activated Carbon
}

\author{
Nurul Syuhada Sulaiman ${ }^{1,2}$, Mohd Hazim Mohamad Amini ${ }^{2, *} \mathbb{C}$, Mohammed Danish ${ }^{1}{ }^{\circledR}$, Othman Sulaiman $^{1}$ \\ and Rokiah Hashim ${ }^{1}$ \\ 1 Bioresource Tech. Division, School of Industrial Technology, Universiti Sains Malaysia, \\ George Town 11800, Penang, Malaysia; nurulsyuhada8496@gmail.com (N.S.S.); \\ danish@usm.my (M.D.); osulaiman@gmail.com (O.S.); hrokiah@gmail.com (R.H.) \\ 2 Faculty of Bioengineering and Technology, Universiti Malaysia Kelantan, Jeli Campus, \\ Jeli 17600, Kelantan, Malaysia \\ * Correspondence: hazimamini@gmail.com; Tel.: +60-9-9477170
}

Citation: Sulaiman, N.S.;

Mohamad Amini, M.H.; Danish, M.; Sulaiman, O.; Hashim, R. Kinetics, Thermodynamics, and Isotherms of Methylene Blue Adsorption Study onto Cassava Stem Activated Carbon. Water 2021, 13, 2936. https: / / doi.org/10.3390/w13202936

Academic Editor: Antonio Zuorro

Received: 21 August 2021 Accepted: 24 September 2021 Published: 19 October 2021

Publisher's Note: MDPI stays neutral with regard to jurisdictional claims in published maps and institutional affiliations.

Copyright: (c) 2021 by the authors. Licensee MDPI, Basel, Switzerland. This article is an open access article distributed under the terms and conditions of the Creative Commons Attribution (CC BY) license (https:/ / creativecommons.org/licenses/by/ $4.0 /)$.

\begin{abstract}
Water treatment using activated carbon is widely accepted, despite its high production cost. Therefore, this study was aimed to investigate the potential of cassava stem in activated carbon form for methylene blue (MB) dye uptake from water. Raw cassava stem (RCS) was also utilized to evaluate the difference between cassava stem in its raw form and after being converted to the activated carbon (ACS). The MB adsorption from water using the RCS and ACS was done in this study. The batch adsorption study showed fast MB uptake by ACS at 60 min contact time, while higher adsorbent dosage and higher $\mathrm{pH}$ contributed to higher adsorption percentage. The thermodynamic study showed positive values of $\Delta \mathrm{H}^{\circ}$ of ACS, indicating that the adsorption process of MB was endothermic. Meanwhile, the negative value of $\Delta \mathrm{G}^{\circ}$ showed that the adsorption processes of MB were spontaneous. The thermodynamic study showed higher fitting to Langmuir isotherm, with data from the kinetic study showing better pseudo-second-order equation fitting, which suggests the chemisorption process had happened. The highest adsorption recorded by ACS was $384.61 \mathrm{mg} / \mathrm{g}$, indicating the possibility of cassava stem as the lower cost raw material for activated carbon production with excellent adsorption characteristics.
\end{abstract}

Keywords: cassava stem; activated carbon; methylene blue; batch adsorption; kinetic studies

\section{Introduction}

Water pollution is considered a severe environmental issue that is harmful to all living things. Thus, numerous techniques have been discovered in order to clean the water from many types of dangerous pollutants. These techniques include reverse osmosis, ion exchange, dialysis or electrodialysis, cementation, electrolyte extraction, oxidationreduction, solvent extraction, evaporation, adsorption, dilution, filtration, and chemical precipitation. Among these techniques, adsorption has been widely practice [1]. Due to several advantages, such as low initial cost, non-complex design, less sensitivity to toxic substances, and ease of operation, the adsorption process was commonly adopted, considering its versatility and high cleaning effectiveness [2]. Focusing on the adsorption technique, the activated carbon has been widely used as the primary adsorption material (adsorbents) for the removal of a wide range of contaminants in liquid and gas phase application. Activated carbon is a useful material that contains a large surface area due to the high porosity level [3]. The increased production cost for producing activated carbon, however, is the main challenge. Researchers have started to find other lower-cost substitutes as precursors or raw materials to overcome this problem.

Biomass wastes, such as food and crops of the agricultural sector, agricultural crop by-products [4], wood industries wastes and residues [5], aquatic plants [6], animal byproducts and wastes [7], municipal wastes [8], and other unwanted materials, have been 
considered as a potentially low-cost precursor to being converted to the activated carbon. Cassava (Manihot esculenta Crantz) stem is one of the biomass wastes that has the potential to be used in a lower cost adsorbent production [9]. The cassava root is the main reason for cassava planting, where people in Asian countries consume it as food with a high carbohydrate source [10]. Meanwhile, given the abundant amount of cassava stem left to decay after harvesting, only a tiny amount of them was used for replanting purposes [11]. It was estimated that, for each mass of root production, $50 \%$ of the amount of the stem was produced based on weight [12]. This gives the first insight into the abundant availability of this material to serve as a precursor for activated carbon production. The cassava plant can be harvested as early as six months of planting, thus confirming sustainability of this material [13].

Dyes and colorants are among the pollutants of our water supply. They come from the water effluent of the textile industry, dyestuff, paper, and plastic that contribute to unpleasant color contamination of the water [14]. The methylene blue (MB) dye is a basic dye that has found its application in many sectors, including pharmaceuticals. Methylene blue ingestion may cause several adverse effects, such as nausea, vomiting, gastritis, and diarrhea [15]. The extensive usage of the MB dye makes it crucial to find the adsorbents with high adsorption capacity towards this type of dye. Recent research in MB adsorption had been done by using materials, such as Algerian palygorskite clay [16], eggshell-treated palm oil fuel ash [17], Syagrus oleracea-activated carbon [18], banana pseudostem biochar [19], $\mathrm{H}_{2} \mathrm{SO}_{4}$ crosslinked magnetic chitosan nanocomposite beads [20], pineapple peel cellulose/magnetic diatomite hydrogels [21], graphene hybridized polydopamine-kaolin composite [22], activated carbon prepared from phosphoric acid-treated eucalyptus residue [23], carbonized watermelon (Citrullus lanatus) rind [24], and oil palm shell biochar [25].

In this work, the abundantly available waste material in the Asian countries, the cassava stem, was converted into activated carbon. Its short rotation of planting and harvesting, quick growth, and wide cultivation for a carbohydrate source are the main advantages that ensure the sustainability of the cassava stem biomass supply. Therefore, this material was chosen as the precursor of activated carbon production. After production, it was tested for potential MB dye removal from contaminated water through batch adsorption studies. The adsorption conditions, including the contact time, adsorbent dosage, $\mathrm{pH}$ of adsorbate, the temperature of the reaction, and initial concentration of the adsorbate, were evaluated. Further analysis on the thermodynamic, isothermic, and kinetic properties was done to understand the adsorption behavior of the produced activated carbon. There is limited information on activated carbon production from cassava stem biomass; thus, this work may give an insight into new potential material for the water treatment process.

\section{Materials and Methods}

\subsection{Materials Preparation}

The cassava stem was obtained from a local farmer in Raub, Pahang, Malaysia. Methylene Blue powder $\left(\mathrm{C}_{16} \mathrm{H}_{18} \mathrm{ClN}_{3} \mathrm{~S} \cdot \mathrm{xH}_{2} \mathrm{O}\right)$ of analytical grade was acquired from SigmaAldrich, Selangor, Malaysia. The freshly obtained raw cassava stem (RCS) was cut into a smaller size, each around $1 \mathrm{~cm}$ to $2 \mathrm{~cm}$, prior to drying in a convection oven (MEMMERT UN160) at $80{ }^{\circ} \mathrm{C} \pm 3$ overnight. The core part of the cassava stem was removed to ensure a homogenous sample part was used for the evaluation. The sample was ground, sieved, and passed through a mesh with a $500-\mu \mathrm{m}$ to $1-\mathrm{mm}$ size sieve. A portion of the RCS particles was used as control adsorbents in their natural form, while the others were used as the precursor of the activated carbon production. The RCS particles were placed inside a graphite reactor and tightly closed with a lid to minimize ash formation before being heated in a furnace with a temperature set at $787^{\circ} \mathrm{C}$ for $146 \mathrm{~min}$, based on the optimum condition found by the previous work by Sulaiman, Hashim, Mohamad Amini, Danish, and Sulaiman [26]. The produced activated carbon (AC) was cooled to room temperature and stored in closed containers for further use. The adsorbate preparation was completed by making $1000 \mathrm{mg} / \mathrm{L} \mathrm{MB}$ dye stock solution by dissolving $1 \mathrm{~g}$ of MB powder in a $1000 \mathrm{~mL}$ 
volumetric flask filled with distilled water. Serial dilution was made to prepare 100, 200, 300, and $400 \mathrm{mg} / \mathrm{L}$ stock solution, respectively. The absorbance value of MB was measured using a UV-vis spectrophotometer (Perkin Elmer Lambda 35, Waltham, MA, USA) before calculating the concentration of $\mathrm{MB}$ using the calibration curve.

\subsection{Adsorption Equilibrium}

Batch adsorption studies were used to investigate the adsorption equilibrium of methylene dye. Different parameters were tested, including the contact time, adsorbent dosage, $\mathrm{pH}$ of adsorbate, temperature of the reaction, and initial concentration of the adsorbate [27]. Each adsorbent with a calculated amount of $0.5 \mathrm{~g} / \mathrm{L}, 1.5 \mathrm{~g} / \mathrm{L}, 3.0 \mathrm{~g} / \mathrm{L}$, and $4.5 \mathrm{~g} / \mathrm{L}$ was added to $250 \mathrm{~mL}$ conical flasks containing $50 \mathrm{~mL}$ of $\mathrm{MB}$ solution with a predetermined initial concentration of $100 \mathrm{mg} / \mathrm{L}, 200 \mathrm{mg} / \mathrm{L}, 300 \mathrm{mg} / \mathrm{L}$, and $400 \mathrm{mg} / \mathrm{L}$. These flasks were then placed in an orbital shaker operated at $100 \mathrm{rpm}$ with computerized temperature-control, maintained at $25^{\circ} \mathrm{C}, 35^{\circ} \mathrm{C}, 45^{\circ} \mathrm{C}$, and $55^{\circ} \mathrm{C}$. After $60 \mathrm{~min}, 120 \mathrm{~min}$, $240 \mathrm{~min}, 480 \mathrm{~min}, 720 \mathrm{~min}$, and $1080 \mathrm{~min}$, the solution was filtered through Whatman No. 2 filter paper. The filtrate was then analyzed using a UV-Vis spectrophotometer (Perkin Elmer Lambda 35) at a wavelength (lambda max) of $660.11 \mathrm{~nm}$, and the lambda max was predetermined from the wavelength scan [28].

\subsection{Thermodynamic Study}

The thermodynamic study was conducted to evaluate the effect of temperature on the adsorption of $\mathrm{MB}$ on the cassava stem-activated carbon, while understanding the nature and feasibility of the reaction [29]. Adsorption was done at temperatures of $298.15 \mathrm{~K}$, $308.15 \mathrm{~K}, 318.15 \mathrm{~K}$, and $328.15 \mathrm{~K}$ with the adsorbate's initial concentrations of $100 \mathrm{mg} / \mathrm{L}$, $200 \mathrm{mg} / \mathrm{L}, 300 \mathrm{mg} / \mathrm{L}$, and $400 \mathrm{mg} / \mathrm{L}$. Plots of the plot of $\operatorname{lnKq}$ versus $1 / \mathrm{T}\left(\mathrm{K}^{-1}\right)$ were completed where $\mathrm{T}$ is the absolute temperature in Kelvin. The changes in standard enthalpy $(\Delta \mathrm{H})$ and standard entropy $(\Delta \mathrm{S})$ were then calculated, according to the following Van't Hoff Equation (1):

$$
\ln K q=\frac{\Delta S}{R}-\frac{\Delta H}{R T}
$$

whereas $\Delta G$ was verified using the following equation:

$$
\Delta \mathrm{G}=-\mathrm{RT} \ln \mathrm{Kq},
$$

where $\mathrm{R}$ is defined as the universal gas constant $\left(8.314 \mathrm{JK}^{-1} \mathrm{~mol}^{-1}\right)$, $\mathrm{T}$ represents the absolute temperature, and $\mathrm{Kq}$ is the thermodynamic equilibrium constant, it was measured as the ratio of adsorbate $(\mathrm{MB})$ concentration at the surface of adsorbent to the adsorbate (MB) concentration remain in the residual solution.

\subsection{Isothermic Study}

A predetermined amount of adsorbate solution of different concentrations was mixed with $1.5 \mathrm{~g}$ of adsorbent in conical flasks and shaken at $100 \mathrm{rpm}$ using the best contact time for adsorption to reach equilibrium in the previously done batch adsorption studies. Experiments were carried out at $25{ }^{\circ} \mathrm{C}, 35^{\circ} \mathrm{C}, 45^{\circ} \mathrm{C}$, and $55^{\circ} \mathrm{C}$ in triplicate. Mixtures were filtered, and the solutions obtained were analyzed using a UV-VIS spectrophotometer [30]. Langmuir and Freundlich isotherm models were used to fit the data obtained. The applicability of the isotherm equations to the adsorption iostherm was compared by the correlation coefficients, $R$-squared value $\left(R^{2}\right)$. The general equation of the Langmuir isotherm is written as Equation (3):

$$
\mathrm{qe}=\mathrm{qmKLCe} / 1+\mathrm{KLCe} .
$$


By plotting the graph, the parameters of the Langmuir adsorption can be determined from the linearized Equation (4):

$$
\mathrm{Ce} / \mathrm{qe}=1 / \mathrm{qmKL}+\mathrm{Ce} / \mathrm{qm},
$$

where Ce is the equilibrium concentration of the adsorbate $(\mathrm{mg} / \mathrm{L})$; qe is the adsorption capacity adsorbed at equilibrium $(\mathrm{mg} / \mathrm{g})$; qm is the maximum adsorption capacity $(\mathrm{mg} / \mathrm{g})$; and $\mathrm{KL}$ is the Langmuir adsorption constant that relates the energy of adsorption $(\mathrm{L} / \mathrm{mg})$.

Freundlich isotherm, on the other hand, can be found by plotting $\ln$ qe versus $\ln \mathrm{Ce}$ that yields a straight line with an intercept of $\ln \mathrm{Kf}$ and a slope of $1 / \mathrm{n}$, and the linear can be written as Equation (5):

$$
\ln \mathrm{qe}=\ln \mathrm{Kf}+1 /(\mathrm{n}) \ln \mathrm{Ce},
$$

where qe is the concentration of the adsorbed species, and $\mathrm{Kf}$ and $\mathrm{n}$ are empirical constants that are commonly temperature-dependent. The value $1 / \mathrm{n}$ represents the linearity of adsorption as the concentration change. The adsorption isotherm becomes more nonlinear as the $n$ value getting larger $[31,32]$.

\subsection{Adsorption Kinetics}

The kinetics studies were conducted to evaluate the adsorption dynamics in relation to time and quantify the rate of adsorption [33]. Fifty milliliters of $100 \mathrm{mg} / \mathrm{L}$ MB stock solution was added into a $250 \mathrm{~mL}$ conical flask containing $1.5 \mathrm{~g} / \mathrm{L}$ dosages of the adsorbent. The adsorption kinetics was run at $25^{\circ} \mathrm{C}$ with an agitation speed of $100 \mathrm{rpm}$ at $60 \mathrm{~min}$, $120 \mathrm{~min}, 240 \mathrm{~min}, 480 \mathrm{~min}, 720 \mathrm{~min}$, and $1080 \mathrm{~min}$ time intervals. The mixture of adsorbent and MB stock solution was then filtered through Whatman No. 2 filter paper after each time interval. Finally, the filtrates were analyzed using UV-VIS spectrophotometer (Perkin Elmer Lambda 35) to determine the remaining MB dye in the solution.

Data from this experiment were fitted into the pseudo-first model, Equation (6):

$$
\log (\mathrm{qe}-\mathrm{qt})=\log \mathrm{qe}-\frac{k p 1}{2.303} \mathrm{t},
$$

where qe and $\mathrm{qt}(\mathrm{mg} / \mathrm{g})$ are the adsorption capacities at equilibrium and time $\mathrm{t}(\mathrm{min})$, respectively. The $k p 1\left(\mathrm{~min}^{-1}\right)$ is the pseudo-first-order rate constant for the kinetic model. A linear form of pseudo-second-order model was also applied Equation (7):

$$
\frac{\mathrm{t}}{\mathrm{qt}}=\frac{1}{\mathrm{~h}}+\frac{1}{\mathrm{qe}} \mathrm{t},
$$

where $\mathrm{h}=\mathrm{k}_{2} \mathrm{qe}^{2}$. The parameters ' $\mathrm{h}$ ' (mg/(g min)) means the initial adsorption rate and the constant $\left(\mathrm{k}_{2}\right)$ can be determined experimentally by plotting $t / q t$ against $t[34,35]$. Other symbols represent the same as in pseudo-first-order.

\section{Results and Discussion}

\subsection{Batch Adsorption Studies}

\subsubsection{Effect of Contact Time on the Adsorption}

The adsorption capacity of both raw and activated carbon derived from the cassava stem was investigated. The results are illustrated in Figure 1. This figure showed that the concentration of $\mathrm{MB}$ dye decreased with an increase in contact time for both adsorbents. The high adsorption process was initially observed, starting from 120 min contact time for RCS. Meanwhile, a high percentage of removal was already observed at the first $60 \mathrm{~min}$ for ACS. Both samples showed a slight improvement in removal percentage at longer contact times and became almost constant at $24 \mathrm{~h}$. The ease of accessibility of pores on the adsorbents caused a rapid adsorption process to occur at the initial contact time. There was a more minor improvement in adsorption percentage that occurred at longer contact time due to the bulky adsorbents that reduced the adhesion sites for adsorbates molecules [36]. 
It was observed that the adsorption capacity for ACS was higher than the RCS. The uptake amount increased by $55 \%$ at the initial $60 \mathrm{~min}$ after the cassava stem was converted into the activated carbon. This occurred as the high temperature in the activation process increased the pore size and volume of the cassava stem. Our previous study supports this fact, indicating a $0.765 \mathrm{~m}^{2} / \mathrm{g}$ surface area for raw cassava stem particles and a maximum surface area of $694.402 \mathrm{~m}^{2} / \mathrm{g}$ for cassava stem activated carbon [9]. Thus, the adhesion sites for adsorbates were increasing, which allowed more adsorbates molecules to be adsorbed onto the surface of the ACS.

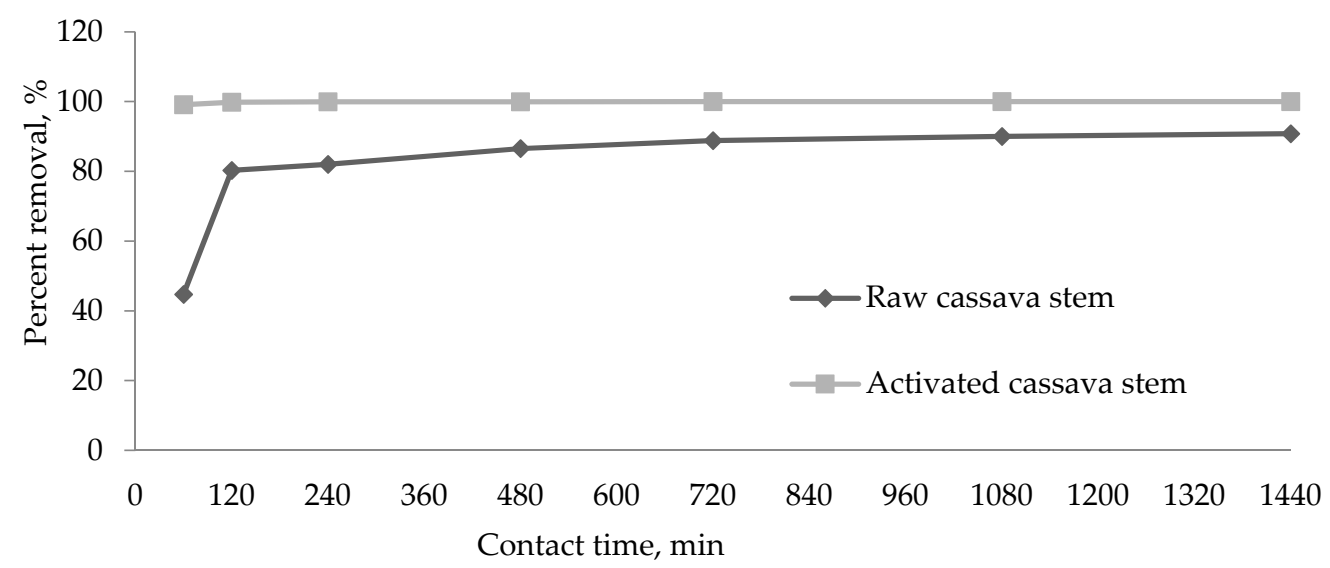

Figure 1. Kinetics of methylene blue adsorption through observation onto raw cassava stem and activated cassava stem at the adsorbent dosage of $1.5 \mathrm{~g} / \mathrm{L}$, Methylene Blue initial concentration of $100 \mathrm{mg} / \mathrm{L}$, and reaction temperature of $25^{\circ} \mathrm{C}$.

\subsubsection{Effect of Adsorbent Dosage on Adsorption of MB Dye}

The capacity of adsorption percentage for a given initial concentration of MB dye can be measured by analyzing the effect of adsorbent dosage [37]. Figure 2 represents the effect of different dosages RCS and ACS on MB dye adsorption. The percentage of dye removal increased with higher adsorbent dosage until it achieved almost constant values after the critical dosage. The percentage of MB dye removal increased by $34.75 \%$ as RCS dosage was increased from $0.5 \mathrm{~g} / \mathrm{L}$ to $4.5 \mathrm{~g} / \mathrm{L}$. Meanwhile, the additional dosage of ACS from $0.5 \mathrm{~g} / \mathrm{L}$ to $4.5 \mathrm{~g} / \mathrm{L}$ showed an increment of $16.37 \%$ for the removal of MB dye. When both RCS and ACS dosage was increased, the free sorption surface and adsorption sites will also be increased. Thus, more MB dye molecules will be adsorbed [38]. The increment of the percentage of removal, along with the increase in adsorbent dosage, for ACS was less than RCS. This happened as ACS already possessed a high percentage of removal at the lowest dosage $(0.5 \mathrm{~g} / \mathrm{L})$. Therefore, the ACS had better efficiency in removal capacity and characteristics than the RCS. This is due to the nature of activated carbon which possessed larger surface area compared to raw sample. From the economic view, the ACS has better economic value than RCS since a small amount of ACS can remove a high amount of contaminant with the activation process records showing $38.7 \%$ in production yield [9]. 


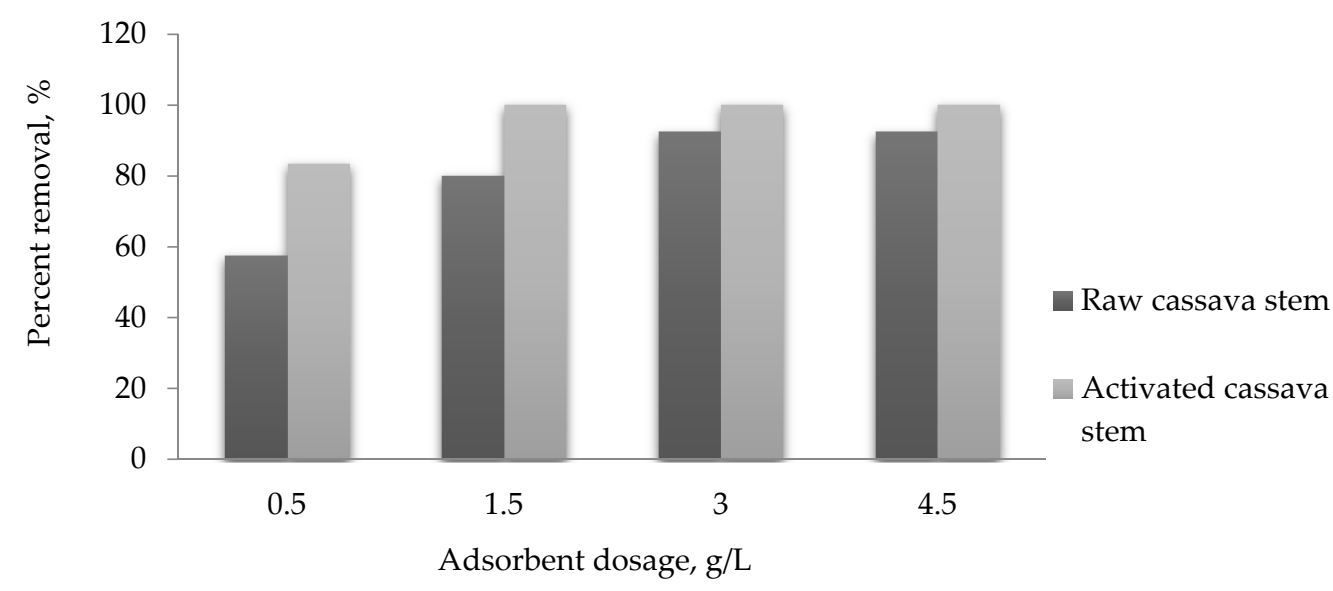

Figure 2. Adsorbent dosage effects on the adsorption of methylene blue onto raw cassava stem and activated cassava stem at Methylene Blue initial concentration of $100 \mathrm{mg} / \mathrm{L}$, reaction temperature of $25^{\circ} \mathrm{C}$, and 1080 min contact time.

\subsubsection{Effect of $\mathrm{pH}$ Adsorbate on Adsorption of MB Dye}

The adsorption of MB dye onto the RCS and ACS at different initial $\mathrm{pH}$ is shown in Figure 3. It demonstrated that the MB dye adsorption by the RCS was strongly $\mathrm{pH}-$ dependent, while, for the ACS, it was less affected by $\mathrm{pH}$ change. For RCS, the MB dye adsorption increased from $36.31 \%$ to $97.95 \%$ as the $\mathrm{pH}$ increased from $\mathrm{pH} 3$ to $\mathrm{pH} 12$. Meanwhile, ACS showed a slight increment of MB removal from $93.57 \%$ to $99.82 \%$ as $\mathrm{pH}$ increased. This showed that ACS could remove MB dye at any $\mathrm{pH}$, but, still, more alkaline $\mathrm{pH}$ gave the best percentage of removal of MB dye.

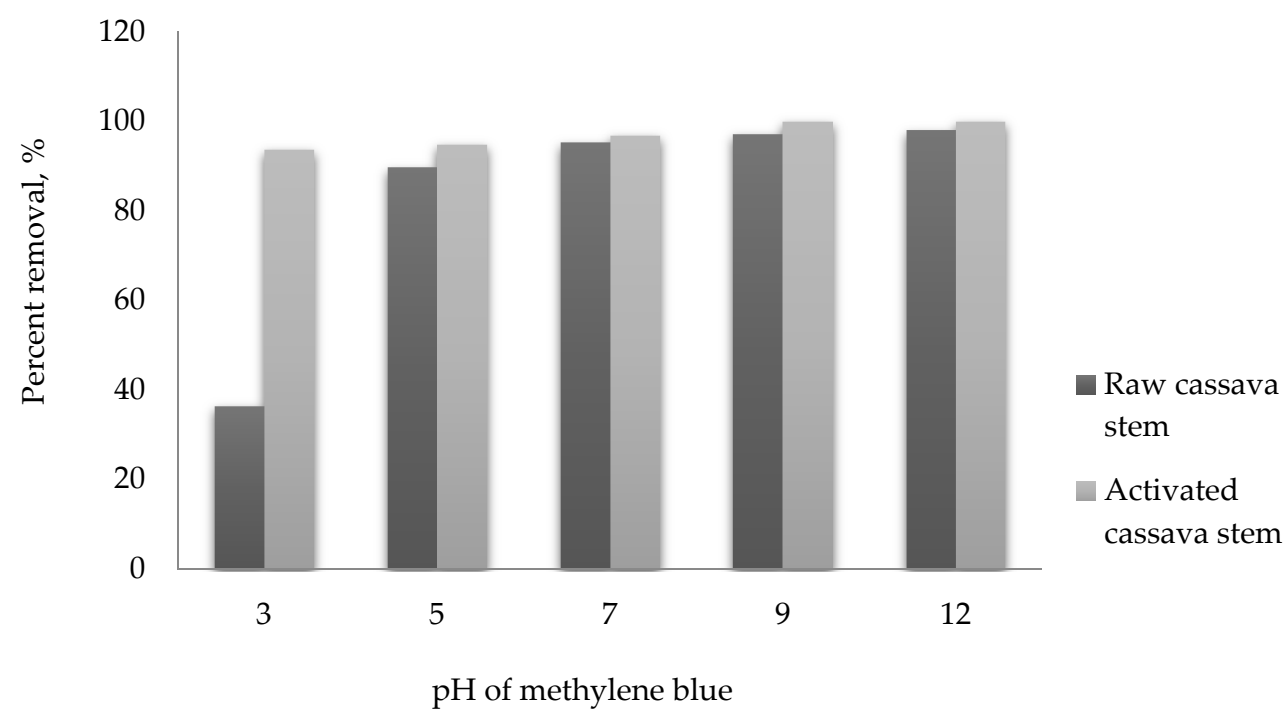

Figure 3. The initial $\mathrm{pH}$ of solution effect on methylene blue adsorption onto raw cassava stem and activated cassava stem at Methylene Blue initial concentration of $100 \mathrm{mg} / \mathrm{L}$, the adsorbent dosage of $1.5 \mathrm{~g} / \mathrm{L}$, and reaction temperature of $25^{\circ} \mathrm{C}$ and $1080 \mathrm{~min}$ contact time.

The $\mathrm{H}^{+}$ions were abundantly present at an acidic $\mathrm{pH}$ range that was likely to compete with the positively charged $\mathrm{MB}$ to attach to the adsorption sites. This explained the lowest adsorption percentage of $\mathrm{MB}$ at an acidic range of $\mathrm{pH}$. Therefore, alkaline $\mathrm{pH}$, especially a $\mathrm{pH}$ value of above 10, is more favorable due to the slight amount of $\mathrm{H}+$ ions and the existence of negatively charged on the surface of the adsorbents. Hence, a more considerable amount of $\mathrm{MB}$ dye can be removed through the electrostatic force of attraction between the positively charged MB and the negatively surface of the adsorbents [39]. Moreover, at $\mathrm{pH}$ values higher than the zero-point charge, $\mathrm{pHzpc}$, the surface of the adsorbents was 
supposed to possess a negative charge with a mainly strong electrostatic attraction towards the cationic MB [40]. The pHzpc values for RCS and ACS produced in this study were 6.53 and 9.20, respectively, measured according to solid addition method [41]. The initial $\mathrm{pH}$ of $50 \mathrm{~mL}, 0.03 \mathrm{M} \mathrm{KNO}_{3}$ solution was adjusted to values between 1.5 and 11.5 by adding $0.1 \mathrm{M}$ $\mathrm{HCl}$ or $0.1 \mathrm{M} \mathrm{NaOH}$ solutions. The same amount of adsorbents was added to each flask, and the final $\mathrm{pH}$ was measured after $24 \mathrm{~h}$. The value of $\mathrm{pHzpc}$ was determined from the intersection of the plot $\mathrm{pH}_{\text {initial }}$ versus $\mathrm{pH}_{\text {final }}$ with line $\mathrm{pH}_{\text {initial }}=\mathrm{pH}_{\text {final. }}$ Another possible mechanism may take place, as well, where the dispersive interactions of the $\pi-\pi$ bond may be a response mechanism due to conjugate systems that exist in $\mathrm{MB}$ molecules. This mechanism can take place between the $\mathrm{C}=\mathrm{C}, \mathrm{N}=\mathrm{C}$, and aromatic rings system [42].

\subsubsection{Effect of Temperature and Initial Concentration on the Adsorption of MB Dye}

The effect of temperature as a function of the initial concentration of MB onto RCS and ACS is shown in Figure 4. These figures revealed that the adsorption of MB onto RCS and ACS was influenced by the temperature, in which high temperature gave a high adsorption percentage. This was due to the increment in the rate of diffusion of the solute through the liquid to the adsorption sites as the temperature increased, which led to the high adsorption capacity of the adsorbents.

These figures also show that the ACS has excellent adsorption characteristics since the ACS was capable of removing the high amount of MB dye ( $>99 \%)$ at low temperature $\left(25^{\circ} \mathrm{C}\right)$, up to the initial concentration of $200 \mathrm{mg} / \mathrm{L}$. Additionally, ACS can remove MB dye at a high percentage ( $>99 \%$ ) for the highest initial concentration $(400 \mathrm{mg} / \mathrm{L})$, at a set temperature of $55^{\circ} \mathrm{C}$ only. The capability of the ACS as adsorbent was good enough as compared to the RCS since the RCS only has a high percentage of removal up to $98 \%$ for the lowest initial concentration $(100 \mathrm{mg} / \mathrm{L})$ and only at a high set temperature, which is $55^{\circ} \mathrm{C}$.

Additionally, high initial concentration did contribute to the relatively small amount of adsorption. This relies on the fact that a high initial concentration of MB possesses high driving forces that force the $\mathrm{MB}$ molecules to go into the pores onto the adsorbents. However, this factor is not strong enough to provide a high adsorption percentage of the $\mathrm{MB}$, due to higher adsorbate ions: adsorption site ratio. Hence, another force from high temperature is required to complete the adsorption of $\mathrm{MB}$, to a great extent in addition to the surface characteristic of these two adsorbents that favor the adsorption of MB.

\section{RCS}

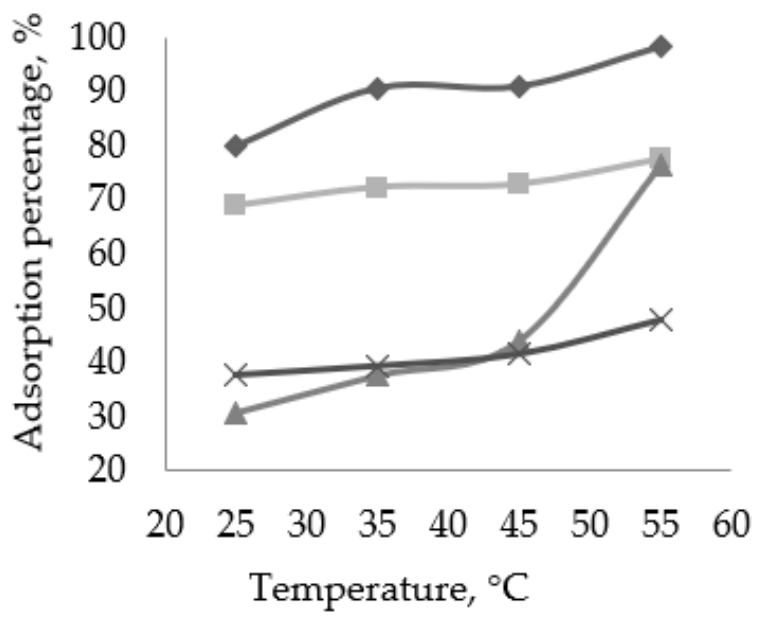

\section{ACS}

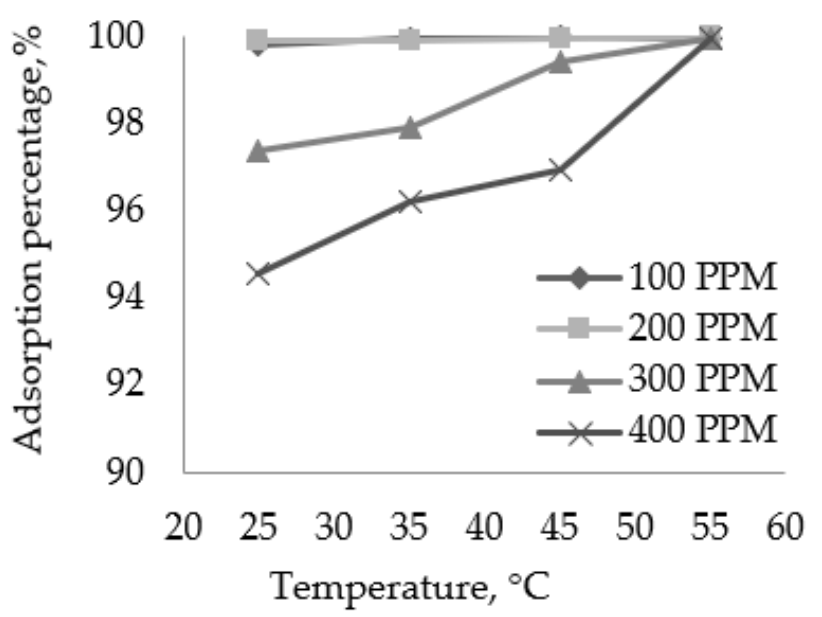

Figure 4. Varying temperatures effect as a function of the initial concentration of methylene blue (MB) onto raw cassava stem (RCS) and activated cassava stem (ACS) at the adsorbent dosage of $1.5 \mathrm{~g} / \mathrm{L}$ and 1080 min contact time. 


\subsection{Thermodynamic Study}

The thermodynamic study was done to evaluate the thermodynamic feasibility of the $\mathrm{MB}$ adsorption onto all adsorbent samples. The parameters calculated included standard change in enthalpy $\left(\Delta \mathrm{H}^{\circ}\right)$, standard change in entropy $\left(\Delta \mathrm{S}^{\circ}\right)$, and the standard change in Gibbs free energy $\left(\Delta \mathrm{G}^{\circ}\right)$. The primary consideration of the thermodynamic study is to determine the spontaneity of the adsorption process through the calculation of $\Delta \mathrm{G}^{\circ}$. Figure 5 showed the plot of $\ln (\mathrm{Kq})$ versus $1 / \mathrm{T}\left(\mathrm{K}^{-1}\right)$ for all types of adsorbents, which gave the values of $\Delta \mathrm{H}^{\circ}$ and $\Delta \mathrm{S}^{\circ}$. Parameters involved included temperatures of $298.15 \mathrm{~K}$, $308.15 \mathrm{~K}, 318.15 \mathrm{~K}$, and $328.15 \mathrm{~K}$, adsorbate's initial concentrations of $100 \mathrm{mg} / \mathrm{L}, 200 \mathrm{mg} / \mathrm{L}$, $300 \mathrm{mg} / \mathrm{L}$, and $400 \mathrm{mg} / \mathrm{L}, 1.5 \mathrm{~g} / \mathrm{L}$ of adsorbent dosage, and $1080 \mathrm{~min}$ of contact time.

\section{RCS}

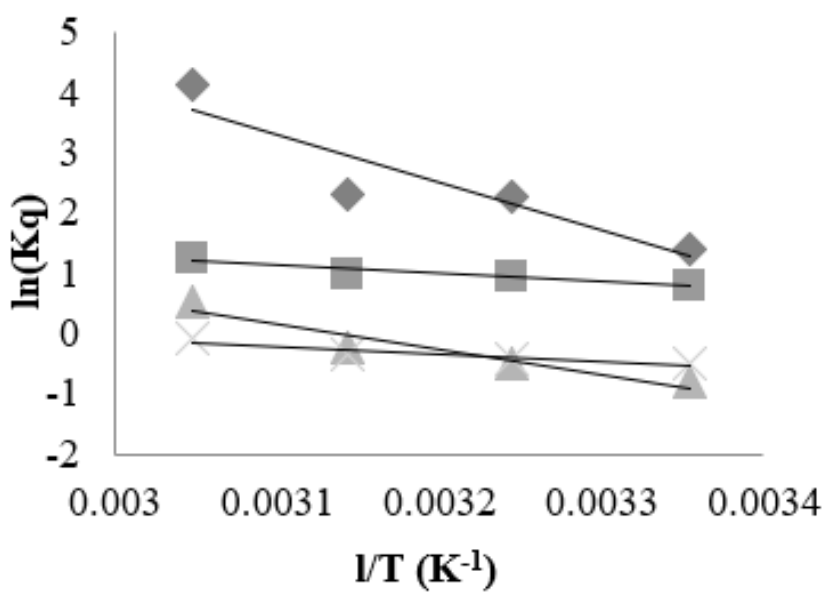

\section{ACS}

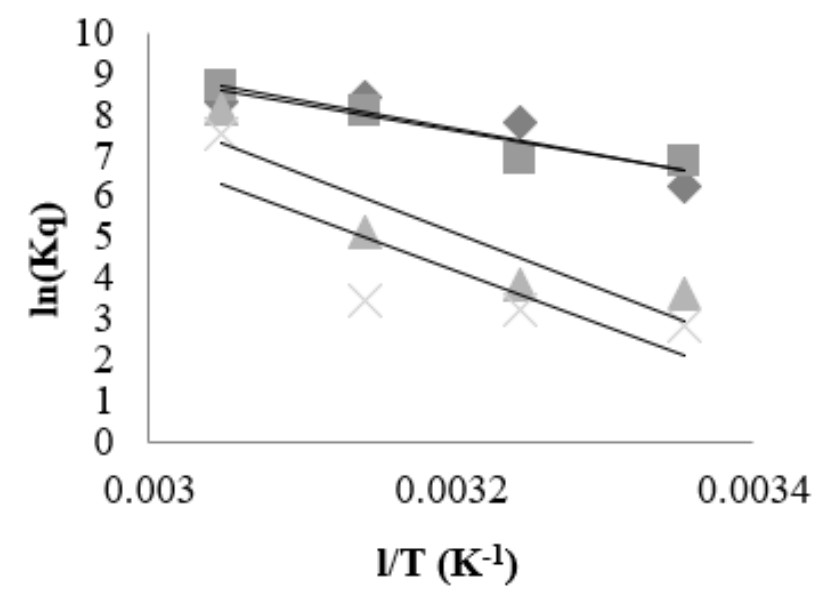

$\rightarrow 100 \mathrm{mg} / \mathrm{L} \backsim 200 \mathrm{mg} / \mathrm{L} \triangle 300 \mathrm{mg} / \mathrm{L} \times 400 \mathrm{mg} / \mathrm{L}$

Figure 5. The plot of $\ln (\mathrm{Kq})$ against $1 / \mathrm{T}\left(\mathrm{K}^{-1}\right)$ for the raw cassava stem (RCS) and activated cassava stem (ACS) was done at temperatures of $298.15 \mathrm{~K}, 308.15 \mathrm{~K}, 318.15 \mathrm{~K}$, and $328.15 \mathrm{~K}$ with the adsorbate's initial concentrations of $100 \mathrm{mg} / \mathrm{L}, 200 \mathrm{mg} / \mathrm{L}$, $300 \mathrm{mg} / \mathrm{L}$, and $400 \mathrm{mg} / \mathrm{L}, 1.5 \mathrm{~g} / \mathrm{L}$ of adsorbent dosage and $1080 \mathrm{~min}$ contact time.

The linear equations, R-squared values, and thermodynamic parameters for the adsorption of MB dye onto all types of cassava stem adsorbents are summarized in Table 1. The RCS and ACS showed positive values of $\Delta \mathrm{H}^{\circ}$, indicating that the adsorption process of MB by both adsorbents was endothermic [43]. Meanwhile, the positive values of $\Delta S^{\circ}$ showed by all types of cassava stem adsorbent RCS and ACS indicated that the surface changes had happened due to the interaction of MB molecules with the active sites of cassava stem adsorbents, mainly hydroxyl groups in lignin and cellulose [44]. It also indicates increased randomness at the solid-solute interface during adsorption processes. The $\mathrm{MB}$ ions replaced the previously adsorbed water on the surface of the adsorbent, creating randomness in the system [45].

The negative value of $\Delta \mathrm{G}^{\circ}$ showed the spontaneous reaction of $\mathrm{MB}$ adsorption. Additionally, the $\Delta \mathrm{G}^{\circ}$ values for all types of adsorbents decreased when the reaction temperature was increased, indicating that high adsorption had been achieved at high temperatures [46]. Table 1 also reveals the adsorption process of MB onto the RCS was spontaneous at all temperatures for the initial concentration of 100 and $200 \mathrm{mg} / \mathrm{L}$. For the initial concentration of $300 \mathrm{mg} / \mathrm{L}$, a higher temperature was needed for the adsorption to be spontaneous. The ACS showed better thermodynamic properties than RCS in terms of adsorption spontaneity. This was due to the result showing that spontaneous adsorption using ACS at an initial concentration of $300 \mathrm{mg} / \mathrm{L}$ can be achieved at low temperatures. 
Table 1. Main thermodynamic analysis for the adsorption of methylene blue by raw cassava stem (RCS) and activated cassava stem (ACS).

\begin{tabular}{|c|c|c|c|c|c|c|c|c|}
\hline \multirow{2}{*}{$\begin{array}{l}\frac{0}{2} \\
\text { हैँ } \\
\text { ñ }\end{array}$} & \multirow{2}{*}{$\begin{array}{c}\text { IAC } \\
*, \mathrm{mg} / \mathrm{L}\end{array}$} & \multirow{2}{*}{$\begin{array}{c}\mathbf{R}^{2} \\
\text { Value }\end{array}$} & \multirow{2}{*}{$\begin{array}{c}\Delta \mathbf{H}^{\circ} \\
(\mathrm{kJ} / \mathrm{mol})\end{array}$} & \multirow{2}{*}{$\begin{array}{c}\Delta \mathrm{S}^{\circ} \\
(\mathrm{kJ} / \mathrm{mol} / \mathrm{K})\end{array}$} & \multicolumn{4}{|c|}{$\Delta \mathrm{G}^{\circ}(\mathrm{kJ} / \mathrm{mol})$} \\
\hline & & & & & $298.15 \mathrm{~K}$ & $308.15 \mathrm{~K}$ & $318.15 \mathrm{~K}$ & $328.15 \mathrm{~K}$ \\
\hline \multirow{4}{*}{ RCS } & 100 & 0.8479 & 66.554 & 0.234 & -3.451 & -5.849 & -6.142 & -11.260 \\
\hline & 200 & 0.9092 & 11.275 & 0.044 & -1.972 & -2.471 & -2.626 & -3.411 \\
\hline & 300 & 0.9190 & 34.512 & 0.108 & 2.013 & 1.295 & 0.632 & -1.429 \\
\hline & 400 & 0.8863 & 11.009 & 0.032 & 1.250 & 1.108 & 0.901 & 0.217 \\
\hline \multirow{4}{*}{ ACS } & 100 & 0.7889 & 84.828 & 0.338 & -15.828 & -19.203 & -22.579 & -25.956 \\
\hline & 200 & 0.9029 & 53.383 & 0.234 & -17.028 & -17.757 & -21.357 & -23.706 \\
\hline & 300 & 0.8278 & 118.799 & 0.423 & -8.965 & -9.870 & -13.531 & -22.169 \\
\hline & 400 & 0.6824 & 133.345 & 0.397 & -7.080 & -8.273 & -9.129 & -20.483 \\
\hline
\end{tabular}

\subsection{Isothermic Study}

Isothermic studies characterize how adsorption molecules were dispersed in the solid and liquid phases to achieve the equilibrium state. The design optimization of an adsorption system is a vital key in studying the isotherm characteristics. The correlation between the adsorption capacity onto the adsorbent surface and adsorbate concentration at a particular temperature can be acquired. In this study, the Langmuir and Freundlich models were fitted to find the most appropriate relationship for the equilibrium curves. This fitting can be used to study the interactions between the adsorbate and adsorbent during adsorption.

\subsubsection{Langmuir Isotherm Model}

The Langmuir isotherm suggested the development of single layer coverage of adsorbate on the external surface of the adsorbent with no further adsorption taking place subsequently. The Langmuir isotherm implies that there is a fixed number of sites on the surface of the adsorbent for the adsorption process to happen, and all these sites are equal in terms of energy [47]. The linear equation of Langmuir isotherm is expressed as $\mathrm{Ce} / \mathrm{qe}=1 / \mathrm{qmKL}+\mathrm{Ce} / \mathrm{qm}$, as described in the methodology part.). Figure 6 presents the plot of $\mathrm{Ce} / \mathrm{qe}$ versus $\mathrm{Ce}$ for all types of cassava stem adsorbents. This plot gives slope 1 /qm and intercepts 1/qmKL, which was used to calculate the qm and KL.

\section{RCS}

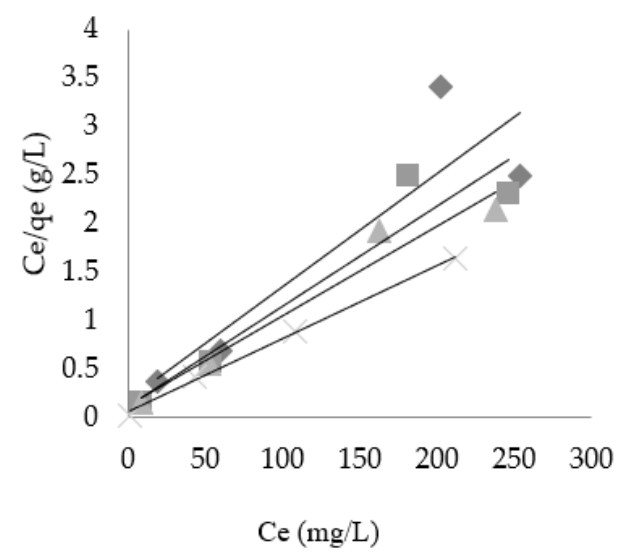

\section{ACS}

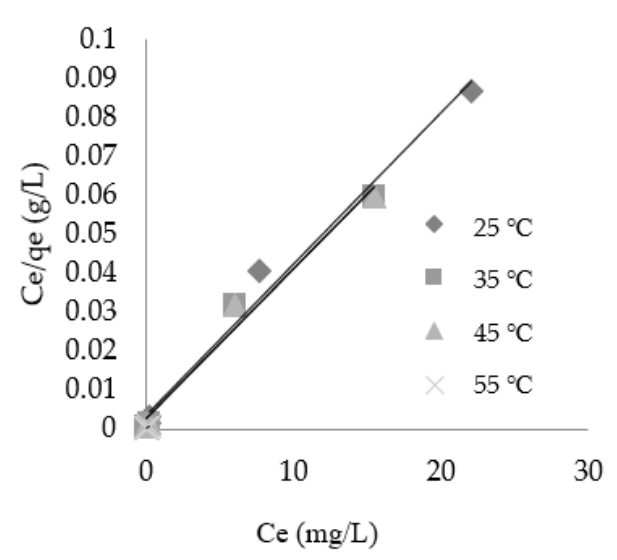

Figure 6. Plot of Ce/qe against Ce for the raw cassava stem (RCS) and activated cassava stem (ACS) fitted for the Langmuir equation done at temperatures of 25, 35, 45, and 55 with the adsorbate's initial concentrations of $100 \mathrm{mg} / \mathrm{L}, 1.5 \mathrm{~g} / \mathrm{L}$ of adsorbent dosage and $1080 \mathrm{~min}$ contact time. 
Table 2 summarizes the parameters for the Langmuir isotherm, including linear equation, $R^{2}$ value, $q \mathrm{~m}, \mathrm{KL}$, and RL. The maximum monolayer coverage capacity (qm) in this study increased with the rise in reaction temperature. At higher temperatures, there will be an increment in the diffusion rate of the adsorbate molecules within the pores and across the external boundary layer of the adsorbent [48]. In addition, the Langmuir constant, $\mathrm{KL}$, in this study, increased with temperature, which confirmed the endothermic nature of the $\mathrm{MB}$ adsorption onto the cassava stem adsorbents [49]. Based on the regression coefficient $\left(R^{2}\right)$ value, all types of cassava stem adsorbents were fit well with the Langmuir isotherm model at each temperature. This also indicated that the cassava stem adsorbents had a homogenous surface in nature [50].

Additionally, further analysis of the Langmuir isotherm can be conveyed using dimensionless separation factor, RL [51]. This separation factor is the essential characteristic of the Langmuir isotherm that describes the type of isotherm. It was expressed as $R L=1 /(1+$ KLCo), where Co is the initial concentration of adsorbate in solution (mg/L), and KL is the Langmuir constant. Accordingly, RL value is the positive numbers that determines the feasibility of the adsorption process to be either unfavorable if RL $>1$; favorable if $0<\mathrm{RL}<$ 1 ; linear adsorption if $R L=1$; and irreversible adsorption if $R L=0$ [52]. In this study, the separation factor, $\mathrm{RL}$, for all types of adsorbents is between 0 and 1 , indicating that the equilibrium sorption was favorable.

Table 2. Langmuir isotherm analysis for the adsorption of MB by raw cassava stem (RCS) and activated cassava stem (ACS).

\begin{tabular}{ccccccc}
\hline Sample & $\begin{array}{c}\text { Temperature } \\
\left({ }^{\circ} \mathbf{C}\right)\end{array}$ & Linear Equation & $\mathbf{R}^{\mathbf{2}}$ Value & $\begin{array}{c}\text { qm } \\
(\mathbf{m g} / \mathbf{g})\end{array}$ & $\begin{array}{c}\text { KL } \\
(\mathbf{L} / \mathbf{m g})\end{array}$ & $\mathbf{R L}$ \\
\hline \multirow{3}{*}{ RCS } & 25 & $\mathrm{y}=0.0117 \mathrm{x}+0.184$ & 0.8053 & 85.4701 & 0.0636 & 0.0372 \\
& 35 & $\mathrm{y}=0.0103 \mathrm{x}+0.1213$ & 0.9112 & 97.0874 & 0.0849 & 0.0282 \\
& 45 & $\mathrm{y}=0.0092 \mathrm{x}+0.1253$ & 0.9577 & 108.6957 & 0.0734 & 0.0324 \\
& 55 & $\mathrm{y}=0.0075 \mathrm{x}+0.0583$ & 0.9966 & 133.3333 & 0.1286 & 0.0188 \\
\multirow{2}{*}{ ACS } & 25 & $\mathrm{y}=0.0039 \mathrm{x}+0.0039$ & 0.9858 & 256.4103 & 1.0000 & 0.0025 \\
& 35 & $\mathrm{y}=0.0039 \mathrm{x}+0.0025$ & 0.9792 & 256.4103 & 1.5600 & 0.0016 \\
& 45 & $\mathrm{y}=0.0038 \mathrm{x}+0.0009$ & 0.9979 & 263.1579 & 4.2222 & 0.0006 \\
& 55 & $\mathrm{y}=0.0026 \mathrm{x}+0.0002$ & 0.9385 & 384.6154 & 13.0000 & 0.0002 \\
\hline
\end{tabular}

\subsubsection{Freundlich Isotherm Fitting}

The multilayer adsorption characteristic onto the heterogeneous surface with irregular distribution of adsorption energy is described by the Freundlich isotherm model [53]. It was expressed in linear form as $\ln \mathrm{qe}=\ln \mathrm{Kf}+\frac{1}{\mathrm{n}} \ln \mathrm{Ce}$, where, qe is the adsorption capacity adsorbed at equilibrium $(\mathrm{mg} / \mathrm{g})$, Ce is the equilibrium concentration of adsorbate $(\mathrm{mg} / \mathrm{L})$, $\mathrm{Kf}$ is the Freundlich isotherm constant, and $\frac{1}{n}$ is the adsorption intensity that varies with the heterogeneity of the adsorbent. The constants $n$ and $\mathrm{Kf}$ are determined from the slope and intercept of the graph of $\ln$ qe versus $\ln C$ e, as shown in Figure 7.

Table 3 presents the linear equation, $\mathrm{R}^{2}$ value, and Freundlich parameters for the $\mathrm{MB}$ adsorption onto all types of cassava stem adsorbents. The adsorption coefficient that signifies the number of adsorbate molecules adsorbed can be determined from the Kf value. Results from this study showed the $\mathrm{Kf}$ value was increasing as the temperature increased from $25{ }^{\circ} \mathrm{C}$ to $55^{\circ} \mathrm{C}$, which can be explained by the increment of the diffusion rate of the $\mathrm{MB}$ into pores of the adsorbents at a higher temperature [54]. Thus, the high adsorption capacity of the MB onto the surface of the cassava stem adsorbents was obtained as the high temperature was utilized during the adsorption process. 
RCS

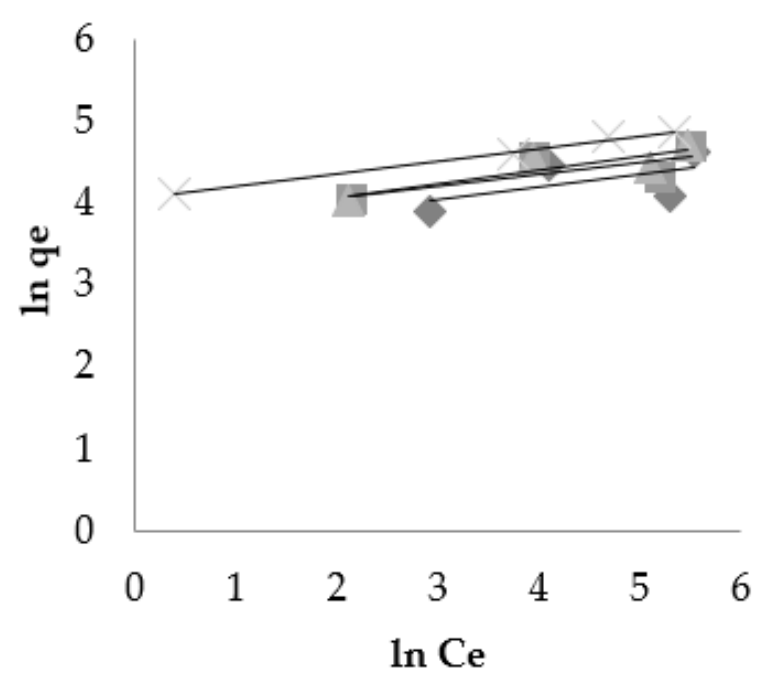

ACS

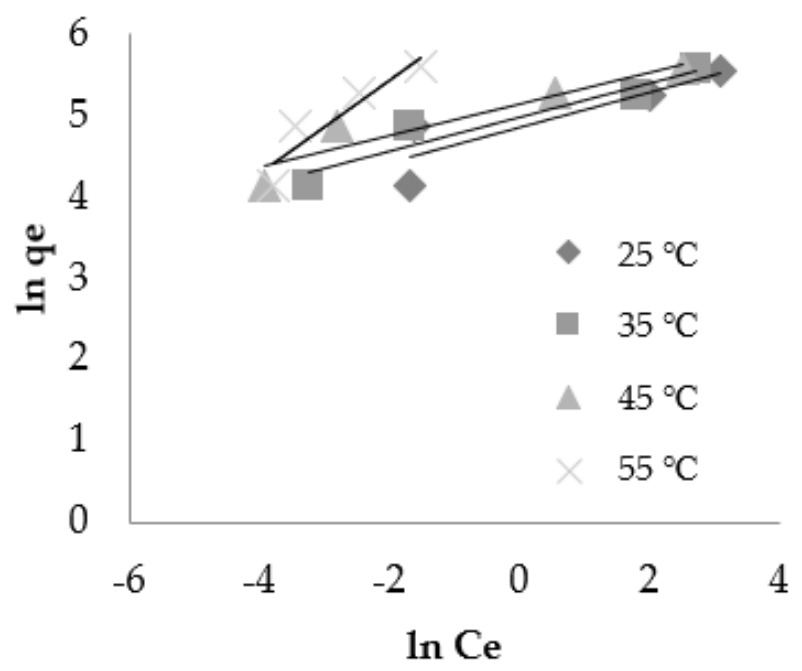

Figure 7. The plot of $\ln (\mathrm{qe})$ versus $\ln$ Ce for raw cassava stem (RCS) and activated cassava stem (ACS) for Freundlich isotherm fitting done at temperatures of $25,35,45$, and $55^{\circ} \mathrm{C}$ with the adsorbate's initial concentrations of $100 \mathrm{mg} / \mathrm{L}, 1.5 \mathrm{~g} / \mathrm{L}$ of adsorbent dosage and 1080 min contact time.

Table 3. Freundlich isotherm analysis for the adsorption of MB by raw cassava stem (RCS) and activated cassava stem (ACS).

\begin{tabular}{ccccccc}
\hline \multirow{2}{*}{ Sample } & $\begin{array}{c}\text { Temperature } \\
\left({ }^{\circ} \mathbf{C}\right)\end{array}$ & Linear Equation & $\mathbf{R}^{2}$ Value & Kf & $\mathbf{n}$ & $\mathbf{1 / n}$ \\
\hline \multirow{3}{*}{ RCS } & 25 & $\mathrm{y}=0.1605 \mathrm{x}+3.5557$ & 0.3337 & 35.0123 & 6.2305 & 0.1605 \\
& 35 & $\mathrm{y}=0.1401 \mathrm{x}+3.7911$ & 0.5713 & 44.3051 & 7.1378 & 0.1401 \\
& 45 & $\mathrm{y}=0.1723 \mathrm{x}+3.7142$ & 0.8082 & 41.0258 & 5.8038 & 0.1723 \\
& 55 & $\mathrm{y}=0.1532 \mathrm{x}+4.0528$ & 0.9948 & 57.5584 & 6.5274 & 0.1532 \\
\multirow{2}{*}{$\mathrm{ACS}$} & 25 & $\mathrm{y}=0.2179 \mathrm{x}+4.8383$ & 0.7742 & 126.2545 & 4.5893 & 0.2179 \\
& 35 & $\mathrm{y}=0.2082 \mathrm{x}+4.9654$ & 0.9226 & 143.3659 & 4.8031 & 0.2082 \\
& 45 & $\mathrm{y}=0.1962 \mathrm{x}+5.1301$ & 0.8803 & 169.0340 & 5.0968 & 0.1962 \\
& 55 & $\mathrm{y}=0.5779 \mathrm{x}+6.5709$ & 0.8603 & 714.0122 & 1.7304 & 0.5779 \\
\hline
\end{tabular}

The nature and strength of the sorption process, as well as the distribution of the active sites, is measured from the slopes $\frac{1}{n}$. The partition between the two phases is independent of the concentration if $\frac{1}{n}=1$. Normal adsorption, which corresponds to the normal L-type Langmuir isotherm, is specified once values of $\frac{1}{n}<1$, and cooperatives adsorption that involve strong interaction between the molecules of adsorbate is specified when the value $\frac{1}{n}>1$. The value of $\frac{1}{n}$ for all types of adsorbent samples in this study presented a value of less than 1. This revealed that the adsorption of the MB onto the surface of cassava stem adsorbents is normal in equivalents to the normal L-type of the Langmuir isotherm [52].

The value of $\mathrm{n}$ ranging from 1 to 10 indicates favorable adsorption. In this study, most of the cassava stem adsorbents displayed $n$ value in the range of 1 to 10 . Consequently, unsuitable adsorption parameters can be avoided in the adsorption of MB dye at an industrial scale. However, the $\mathrm{R}^{2}$ value obtained from the linear plot of $\ln$ qe versus $\ln$ Ce for all types of cassava stem adsorbents showed poor agreement with the Freundlich isotherm model. Therefore, the adsorption of MB onto the adsorbent samples did not perform multilayer adsorption.

Table 4 summarizes some recently researched adsorbents for MB adsorption. The ACS showed a considerably high adsorption percentage for MB with a maximum of $384.61 \mathrm{mg} / \mathrm{g}$ compared to other materials. Ease of acquisition, low cost, and high adsorption efficiency of ACS are among the advantages of this material. 
Table 4. Comparison of maximum adsorption values of the different adsorbent for methylene blue.

\begin{tabular}{ccc}
\hline Adsorbent & Maximum Adsorption, mg/g & Reference \\
\hline Phosphoric acid-treated eucalyptus residue activated carbon & 977.00 & {$[23]$} \\
Demineralized low rank coal (Rawdon) activated carbon & 841.93 & {$[55]$} \\
Eggshell-treated palm oil fuel ash & 714.29 & {$[17]$} \\
Cassava stem activated carbon & 384.61 & This work \\
Coffee husk activated carbon by hydrothermal methods & 357.38 & {$[56]$} \\
Double cross-linked graphene aerogels & 332.23 & {$[57]$} \\
Carbonized watermelon (Citrullus lanatus) rind & 200.00 & {$[24]$} \\
Banana pseudostem biochar & 146.23 & {$[19]$} \\
Raw cassava stem particles & 133.33 & This work \\
Pineapple peel cellulose/magnetic diatomite hydrogels & 57.94 & {$[21]$} \\
Algerian palygorskite clay & 39.66 & {$[16]$} \\
Graphene hybridized polydopamine-kaolin composite & 30.00 & {$[22]$} \\
Syagrus oleracea-activated carbon & 20.41 & {$[18]$} \\
$\mathrm{H}_{2} \mathrm{SO}_{4}$ crosslinked magnetic chitosan nanocomposite beads & 20.00 & {$[20]$} \\
Oil palm shell biochar & & {$[25]$} \\
\hline
\end{tabular}

\subsection{Kinetic Studies}

The rate uptake of MB molecules onto the adsorbents' surface was studied using pseudo-first-order and pseudo-second-order kinetic models. The correlation coefficient, $\mathrm{R}^{2}$, was used to verify the validity of the applied models. The kinetic studies were critical to optimize and design the handling of particular effluent [58].

\subsubsection{Pseudo-First Order Kinetic Model}

The pseudo-first-order equation was expressed as $\log (q e-q t)=\log (q e)-\left(k_{1} / 2.303\right)$.t. Plots of $\log (\mathrm{qe}-\mathrm{qt})$ against time for all types of cassava stem adsorbents are displayed in Figure 8. The parameters obtained from the plot of linearized equation, namely first-order rate constant, $\mathrm{k}_{1}$, and adsorption capacity at equilibrium, qe, are presented in Table 5, along with the linear equation and $\mathrm{R}^{2}$ value for each cassava stem adsorbents. It was observed that the MB adsorption onto each type of cassava stem adsorbents did not fit well with the pseudo-first-order kinetic model.

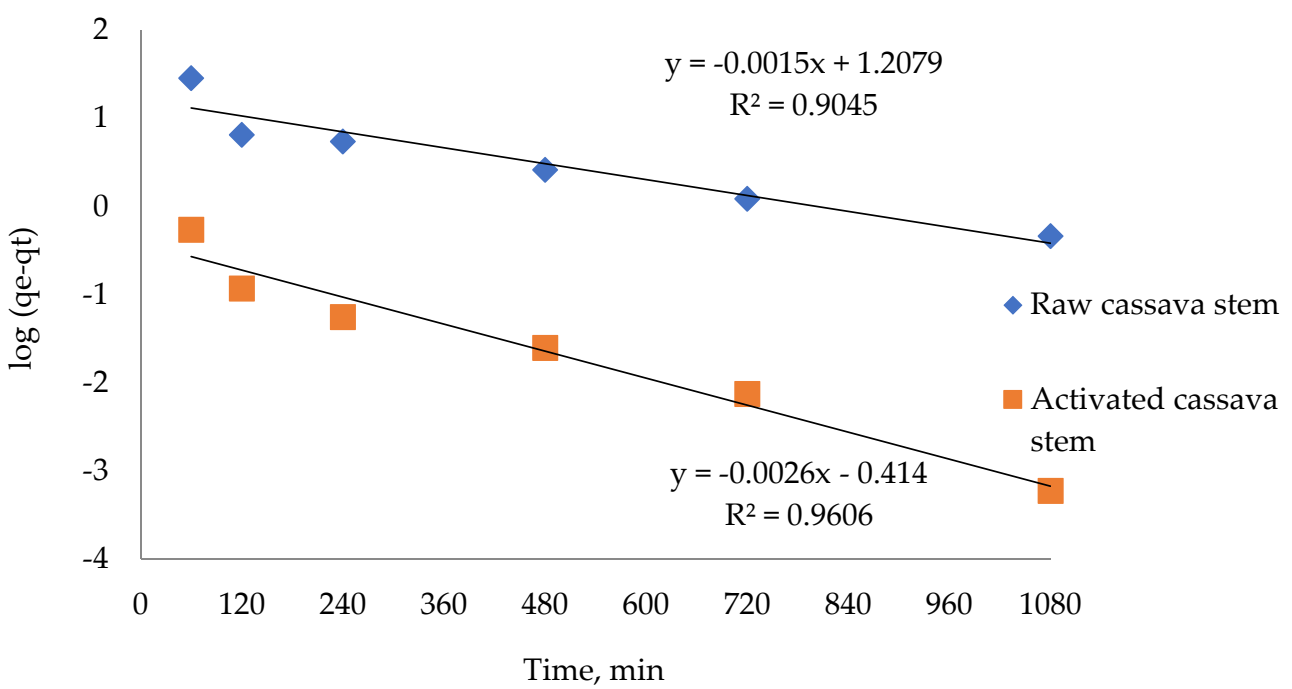

Figure 8. Plot of $\log (\mathrm{qe}-\mathrm{qt})$ versus time for raw cassava stem and activated cassava stem. The experiment was done at $25^{\circ} \mathrm{C}$ with an initial concentration of $100 \mathrm{mg} / \mathrm{L}$ for $\mathrm{MB}, 1.5 \mathrm{~g} / \mathrm{L}$ dosage of the adsorbent and different contact times of $60 \mathrm{~min}, 120 \mathrm{~min}, 240 \mathrm{~min}, 480 \mathrm{~min}, 720 \mathrm{~min}$, and $1080 \mathrm{~min}$. 
Table 5. The pseudo-first-order analysis for the adsorption of MB by raw cassava stem (RCS) and activated cassava stem (ACS).

\begin{tabular}{ccccc}
\hline Sample & Linear Equation & $\mathbf{R}^{\mathbf{2}}$ Value & $\begin{array}{c}\mathbf{q e} \\
(\mathbf{m g} / \mathbf{g})\end{array}$ & $\begin{array}{c}\mathbf{k}_{\mathbf{1}} \\
\left(\mathbf{m i n}^{-\mathbf{1}}\right)\end{array}$ \\
\hline RCS & $\mathrm{y}=-0.0015 \mathrm{x}+1.2079$ & 0.9045 & 16.1399 & 0.0035 \\
$\mathrm{ACS}$ & $\mathrm{y}=-0.0026 \mathrm{x}-0.4140$ & 0.9606 & 2.5942 & 0.0060 \\
\hline
\end{tabular}

\subsubsection{Pseudo-Second Order Kinetic Model}

A linear form of the pseudo-second-order kinetic model was expressed as $\mathrm{t} / \mathrm{qt}=1 / \mathrm{h}$ $+(1 / q e) \cdot t$, where $h$ is the initial sorption rate as $q t / t=0$; thus, $h=k_{2} q_{2}$. The plot of $t / q t$ versus time for all types of cassava stem adsorbents is presented in Figure 9. The plots give the adsorption capacity at equilibrium (qe), as well as the second-order rate constant for each cassava stem adsorbents studied. Table 6 tabulates the pseudo-second-order parameters and the linear equation and corresponding correlation coefficients for each type of cassava stem adsorbents. The $\mathrm{h}$ value was much higher for the ACS sample. This simply indicated that the ACS samples have a higher initial rate of adsorption compared to RCS. The value of the correlation coefficient for both types of cassava stem adsorbents is near unity. This fact specified that the rate of MB adsorptions onto the cassava stem adsorbents was fit better by the pseudo-second-order kinetic model, which suggested the chemisorption process [59].

Table 6. The pseudo-second-order analysis for the adsorption of methylene blue by raw cassava stem (RCS) and activated cassava stem (ACS).

\begin{tabular}{cccccc}
\hline Sample & Linear Equation & $\mathbf{R}^{2}$ Value & $\begin{array}{c}\mathbf{q e} \\
(\mathbf{m g} / \mathbf{g})\end{array}$ & $\begin{array}{c}\mathbf{k}_{\mathbf{2}} \\
\mathbf{( g / m g / m i n})\end{array}$ & $\mathbf{h}(\mathbf{m g} / \mathbf{g} / \mathbf{m i n})$ \\
\hline RCS & $\mathrm{y}=0.0172 \mathrm{x}+0.6767$ & 0.9993 & 58.1395 & 0.0004 & 1.4778 \\
$\mathrm{ACS}$ & $\mathrm{y}=0.0160 \mathrm{x}+0.0057$ & 1.0000 & 62.5000 & 0.0449 & 175.4386 \\
\hline
\end{tabular}

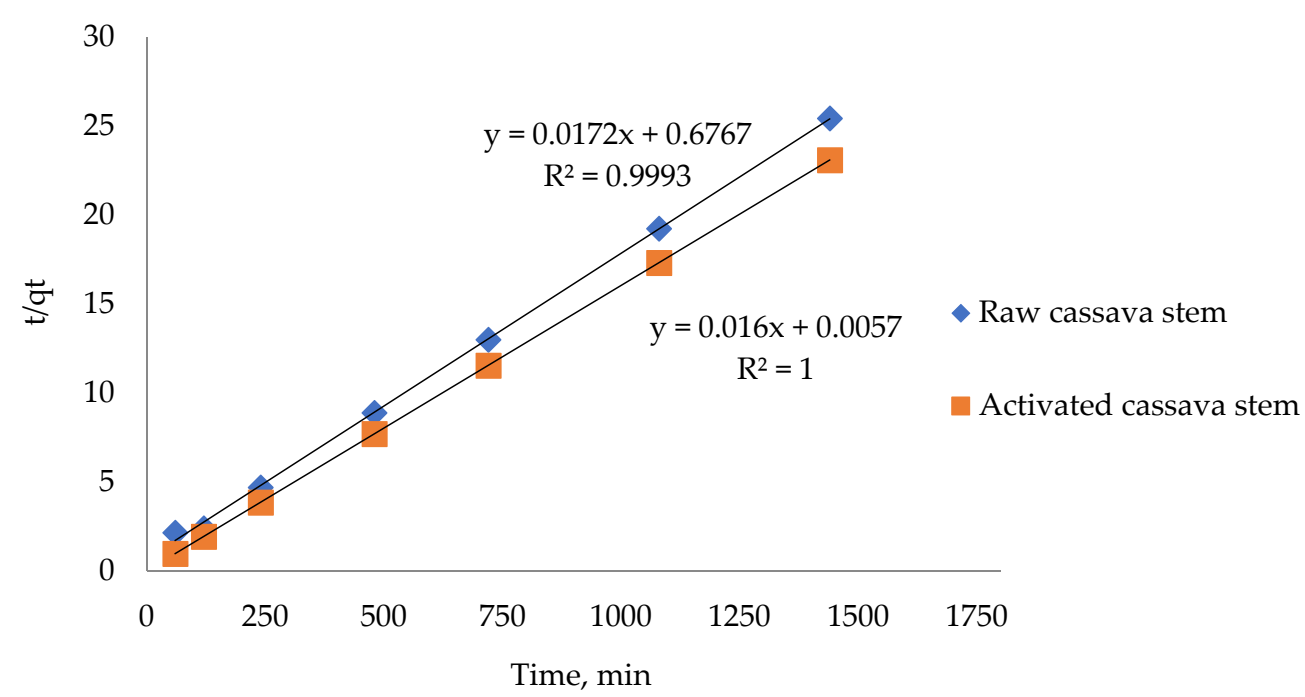

Figure 9. The plot of $\mathrm{t} / \mathrm{qt}$ versus time for raw cassava stem and activated cassava stem. The experiment was done at $25{ }^{\circ} \mathrm{C}$ with an initial concentration of $100 \mathrm{mg} / \mathrm{L}$ for MB, $1.5 \mathrm{~g} / \mathrm{L}$ dosages of the adsorbent, and different contact times of $60 \mathrm{~min}, 120 \mathrm{~min}, 240 \mathrm{~min}, 480 \mathrm{~min}, 720 \mathrm{~min}$, and $1080 \mathrm{~min}$.

\section{Conclusions}

The MB adsorption from water using the RCS and ACS was done in this study. Batch adsorption study showed faster MB uptake by ACS (60 min contact time) than RCS (120 min contact time). Higher adsorbent dosage and higher $\mathrm{pH}$ contribute to a higher adsorption 
percentage. The pHzpc values for RCS and ACS produced in this study were 6.53 and 9.20. The thermodynamic study showed positive values of $\Delta \mathrm{H}^{\circ}$ of RCS and ACS, indicating that the adsorption process of MB by these two adsorbents is endothermic. The negative value of $\Delta \mathrm{G}^{\circ}$ shows that the adsorption processes of $\mathrm{MB}$ are spontaneous. The adsorption isotherm showed higher fitting to Langmuir isotherm for both samples, with the highest adsorption recorded by ACS $(384.61 \mathrm{mg} / \mathrm{g})$. The kinetic study showed higher $\mathrm{R}^{2}$ by pseudo-second-order equation, which suggests the chemisorption process for both samples. Meanwhile, the RCS recorded $133.33 \mathrm{mg} / \mathrm{g}$ adsorption capacity for MB. Considering 2.88 times higher ACS adsorption capacity than RCS, it is a significant improvement of the material as an $\mathrm{MB}$ adsorbent. It can be concluded that producing activated carbon from cassava stem is worthwhile, taking into account the adsorption efficiency, year-round availability, and low cost of raw material.

Author Contributions: Conceptualization, R.H. and O.S.; methodology, N.S.S.; software, M.D.; validation, R.H., M.D. and O.S.; formal analysis, N.S.S. and M.H.M.A.; investigation, N.S.S. and M.H.M.A.; resources, R.H.; writing—original draft preparation, N.S.S.; writing—review and editing, M.H.M.A. and R.H.; supervision, R.H.; project administration, R.H.; funding acquisition, R.H. and M.H.M.A. All authors have read and agreed to the published version of the manuscript.

Funding: This research received no external funding, and The APC was funded by Universiti Malaysia Kelantan (R/STA/A 1300/01046A/004/2021/00924) and the Ministry of Higher Education Malaysia (R/FRGS/A1300/01046A/003/2020/00897).

Institutional Review Board Statement: Not applicable.

Informed Consent Statement: Not applicable.

Data Availability Statement: Data are available on-demand from the corresponding author.

Acknowledgments: The authors acknowledge Ministry of Education Malaysia for My Brain scholarship to Nurul Syuhada Sulaiman.

Conflicts of Interest: The authors declare no conflict of interest.

\section{References}

1. Roy, A.; Thakur, B.; Debsarkar, A. Water pollution and treatment technologies. In Environmental Management: Issues and Concerns in Developing Countries; Sikdar, P.K., Ed.; Springer International Publishing: Cham, Switzerland, 2021; pp. 79-106.

2. Foo, K.Y.; Hameed, B.H. An overview of dye removal via activated carbon adsorption process. Desalination Water Treat. 2010, 19, 255-274. [CrossRef]

3. Larasati, A.; Fowler, G.D.; Graham, N.J.D. Insights into chemical regeneration of activated carbon for water treatment. J. Environ. Chem. Eng. 2021, 9, 105555. [CrossRef]

4. Yahya, M.A.; Al-Qodah, Z.; Ngah, C.Z. Agricultural bio-waste materials as potential sustainable precursors used for activated carbon production: A review. Renew. Sustain. Energy Rev. 2015, 46, 218-235. [CrossRef]

5. Danish, M.; Ahmad, T. A review on utilisation of wood biomass as a sustainable precursor for activated carbon production and application. Renew. Sustain. Energy Rev. 2018, 87, 1-21. [CrossRef]

6. Li, J.; Wu, Q. Activated carbon derived from harmful aquatic plant for high stable supercapacitors. Chem. Phys. Lett. 2018, 691, 238-242. [CrossRef]

7. Koutcheiko, S.; Monreal, C.; Kodama, H.; McCracken, T.; Kotlyar, L. Preparation and characterisation of activated carbon derived from the thermo-chemical conversion of chicken manure. Bioresour. Technol. 2007, 98, 2459-2464. [CrossRef]

8. Sullivan, G.; Prigmore, R.; Knight, P.; Godfrey, A. Activated carbon biochar from municipal waste as a sorptive agent for the removal of polyaromatic hydrocarbons (PAHs), phenols and petroleum based compounds in contaminated liquids. J. Environ. Manag. 2019, 251, 109551. [CrossRef] [PubMed]

9. Simate, G.S.; Ndlovu, S. The removal of heavy metals in a packed bed column using immobilized cassava peel waste biomass. J. Ind. Eng. Chem. 2015, 21, 635-643. [CrossRef]

10. Chauynarong, N.; Elangovan, A.V.; Iji, P.A. The potential of cassava products in diets for poultry. World's Poult. Sci. J. 2009, 65, 23-36. [CrossRef]

11. Granado, M.P.P.; Suhogusoff, Y.V.M.; Santos, L.R.O.; Yamaji, F.M.; Conti, A.C.D. Effects of pressure densification on strength and properties of cassava waste briquettes. Renew. Energy 2021, 167, 306-312. [CrossRef]

12. Wei, M.; Zhu, W.; Xie, G.; Lestander, T.A.; Xiong, S. Cassava stem wastes as potential feedstock for fuel ethanol production: A basic parameter study. Renew. Energy 2015, 83, 970-978. [CrossRef] 
13. Polthanee, A.; Janthajam, C.; Promkhambut, A. Growth, yield and starch content of cassava following rainfed. Int. J. Agric. Res. 2014, 9, 319-324. [CrossRef]

14. Tetteh, E.K.; Rathilal, S. Application of magnetised nanomaterial for textile effluent remediation using response surface methodology. Mater. Today Proc. 2021, 38, 700-711. [CrossRef]

15. Ghosh, D.; Bhattacharyya, K.G. Adsorption of methylene blue on kaolinite. Appl. Clay Sci. 2002, 20, 295-300. [CrossRef]

16. Youcef, L.D.; Belaroui, L.S.; López-Galindo, A. Adsorption of a cationic methylene blue dye on an Algerian palygorskite. Appl. Clay Sci. 2019, 179, 105145. [CrossRef]

17. Hasan, R.; Chong, C.C.; Setiabudi, H.D.; Jusoh, R.; Jalil, A.A. Process optimisation of methylene blue adsorption onto eggshelltreated palm oil fuel ash. Environ. Technol. Innov. 2019, 13, 62-73. [CrossRef]

18. dos Santos, K.J.L.; dos Santos, G.E.d.S.; de Sá, Í.M.G.L.; de Carvalho, S.H.V.; Soletti, J.I.; Meili, L.; Duarte, J.L.d.S.; Bispo, M.D.; Dotto, G.L. Syagrus oleracea-activated carbon prepared by vacuum pyrolysis for methylene blue adsorption. Environ. Sci. Pollut. Res. 2019, 26, 16470-16481. [CrossRef]

19. Liu, S.; Li, J.; Xu, S.; Wang, M.; Zhang, Y.; Xue, X. A modified method for enhancing adsorption capability of banana pseudostem biochar towards methylene blue at low temperature. Bioresour. Technol. 2019, 282, 48-55. [CrossRef]

20. Rahmi; Ishmaturrahmi; Mustafa, I. Methylene blue removal from water using H2SO4 crosslinked magnetic chitosan nanocomposite beads. Microchem. J. 2019, 144, 397-402. [CrossRef]

21. Dai, H.; Huang, Y.; Zhang, Y.; Zhang, H.; Huang, H. Green and facile fabrication of pineapple peel cellulose/magnetic diatomite hydrogels in ionic liquid for methylene blue adsorption. Cellulose 2019, 26, 3825-3844. [CrossRef]

22. He, K.; Zeng, G.; Chen, A.; Huang, Z.; Peng, M.; Huang, T.; Chen, G. Graphene hybridised polydopamine-kaolin composite as effective adsorbent for methylene blue removal. Compos. Part B Eng. 2019, 161, 141-149. [CrossRef]

23. Han, Q.; Wang, J.; Goodman, B.A.; Xie, J.; Liu, Z. High adsorption of methylene blue by activated carbon prepared from phosphoric acid treated eucalyptus residue. Powder Technol. 2020, 366, 239-248. [CrossRef]

24. Jawad, A.H.; Razuan, R.; Appaturi, J.N.; Wilson, L.D. Adsorption and mechanism study for methylene blue dye removal with carbonised watermelon (Citrullus lanatus) rind prepared via one-step liquid phase H2SO4 activation. Surf. Interfaces 2019, 16, 76-84. [CrossRef]

25. Kong, S.-H.; Lam, S.S.; Yek, P.N.Y.; Liew, R.K.; Ma, N.L.; Osman, M.S.; Wong, C.C. Self-purging microwave pyrolysis: An innovative approach to convert oil palm shell into carbon-rich biochar for methylene blue adsorption. J. Chem. Technol. Biotechnol. 2019, 94, 1397-1405. [CrossRef]

26. Sulaiman, N.S.; Hashim, R.; Amini, M.H.M.; Danish, M.; Sulaiman, O. Optimization of activated carbon preparation from cassava stem using response surface methodology on surface area and yield. J. Clean. Prod. 2018, 198, 1422-1430. [CrossRef]

27. Ibrahim, W.M.H.W.; Amini, M.H.M.; Sulaiman, N.S.; Kadir, W.R.A. Powdered activated carbon prepared from Leucaena leucocephala biomass for cadmium removal in water purification process. Arab. J. Basic Appl. Sci. 2019, 26, 30-40. [CrossRef]

28. Rauf, M.A.; Meetani, M.A.; Khaleel, A.; Ahmed, A. Photocatalytic degradation of Methylene Blue using a mixed catalyst and product analysis by LC/MS. Chem. Eng. J. 2010, 157, 373-378. [CrossRef]

29. Bedin, K.C.; Martins, A.C.; Cazetta, A.L.; Pezoti, O.; Almeida, V.C. KOH-activated carbon prepared from sucrose spherical carbon: Adsorption equilibrium, kinetic and thermodynamic studies for Methylene Blue removal. Chem. Eng. J. 2016, 286, 476-484. [CrossRef]

30. Lee, Y.C.; Amini, M.H.M.; Sulaiman, N.S.; Mazlan, M.; Boon, J.G. Batch adsorption and isothermic studies of malachite green dye adsorption using Leucaena leucocephala biomass as potential adsorbent in water treatment. Songklanakarin J. Sci. Technol. 2018, 40, 563-569.

31. Do, D.D. Adsorption Analysis: Equilibria and Kinetics; Yang, R.T., Ed.; Imperial College Press: London, UK, 1998.

32. Berkowitz, B.; Dror, I.; Yaron, B. Sorption, retention and release of contaminants. In Contaminant Geochemistry: Transport and Fate in the Subsurface Environment; Springer: Berlin/Heidelberg, Germany, 2014.

33. Cazetta, A.L.; Vargas, A.M.M.; Nogami, E.M.; Kunita, M.H.; Guilherme, M.R.; Martins, A.C.; Silva, T.L.; Moraes, J.C.G.; Almeida, V.C. $\mathrm{NaOH}$-activated carbon of high surface area produced from coconut shell: Kinetics and equilibrium studies from the methylene blue adsorption. Chem. Eng. J. 2011, 174, 117-125. [CrossRef]

34. Ho, Y.-S.; McKay, G. Pseudo-second order model for sorption process. Process. Biochem. 1999, 34, 451-465. [CrossRef]

35. Qiu, H.; Lv, L.; Pan, B.-C.; Zhang, Q.-J.; Zhang, W.-M.; Zhang, Q.-X. Critical review in adsorption kinetic models. J. Zheijang Univ. Sci. A 2009, 10, 716-724. [CrossRef]

36. Malik, A.; Khan, A.; Shah, N.; Khan, M.S. The kinetics and equilibrium thermodynamics study on the removal of direct blue and titan yellow dyes from aqueous media by modified rice husk char. Z. Phys. Chem. 2020, 234, 485-503. [CrossRef]

37. Rafatullah, M.; Sulaiman, O.; Hashim, R.; Amini, M. Adsorption of copper (II) ions onto surfactant-modified oil palm leaf powder. J. Dispers. Sci. Technol. 2011, 32, 1641-1648. [CrossRef]

38. Anisuzzaman, S.M.; Joseph, C.G.; Taufiq-Yap, Y.H.; Krishnaiah, D.; Tay, V.V. Modification of commercial activated carbon for the removal of 2,4-dichlorophenol from simulated wastewater. J. King Saud Univ. Sci. 2015, 27, 318-330. [CrossRef]

39. Atouani, S.E.; Belattmania, Z.; Reani, A.; Tahiri, S.; Aarfane, A.; Bentiss, F.; Jama, C.; Zrid, R.; Sabour, B. Brown seaweed Sargassum muticum as low-cost biosorbent of methylene blue. Int. J. Environ. Res. 2019, 13, 131-142. [CrossRef]

40. MomČiloviĆ, M.Z.; Onjia, A.E.; PurenoviĆ, M.M.; Zarubica, A.R.; RandeloviĆ, M.S. Removal of a cationic dye from water by activated pinecones. J. Serb. Chem. Soc. 2012, 77, 761-774. [CrossRef] 
41. Ngah, W.S.W.; Hanafiah, M.A.K.M. Adsorption of copper on rubber (Hevea brasiliensis) leaf powder: Kinetic, equilibrium and thermodynamic studies. Biochem. Eng. J. 2008, 39, 521-530. [CrossRef]

42. Macedo, J.d.S.; Júnior, N.B.d.C.; Almeida, L.E.; Vieira, E.F.d.S.; Cestari, A.R.; Gimenez, I.d.F.; Carreño, N.L.V.; Barreto, L.S. Kinetic and calorimetric study of the adsorption of dyes on mesoporous activated carbon prepared from coconut coir dust. J. Colloid Interface Sci. 2006, 298, 515-522. [CrossRef]

43. Zuorro, A.; Maffei, G.; Lavecchia, R. Kinetic modeling of azo dye adsorption on non-living cells of Nannochloropsis oceanica. J. Environ. Chem. Eng. 2017, 5, 4121-4127. [CrossRef]

44. Utomo, H.D.; Phoon, R.Y.N.; Shen, Z.; Ng, L.H.; Lim, Z.B. Removal of methylene blue using chemically modified sugarcane bagasse. Nat. Resour. 2015, 6, 209-220. [CrossRef]

45. Nasuha, N.; Hameed, B.H. Adsorption of methylene blue from aqueous solution onto NaOH-modified rejected tea. Chem. Eng. J. 2011, 166, 783-786. [CrossRef]

46. Jia, Z.; Li, Z.; Ni, T.; Li, S. Adsorption of low-cost absorption materials based on biomass (Cortaderia selloana flower spikes) for dye removal: Kinetics, isotherms and thermodynamic studies. J. Mol. Liq. 2017, 229, 285-292. [CrossRef]

47. Zhang, W.; An, Y.; Li, S.; Liu, Z.; Chen, Z.; Ren, Y.; Wang, S.; Zhang, X.; Wang, X. Enhanced heavy metal removal from an aqueous environment using an eco-friendly and sustainable adsorbent. Sci. Rep. 2020, 10, 16453. [CrossRef] [PubMed]

48. Hameed, B.H.; Mahmoud, D.K.; Ahmad, A.L. Equilibrium modeling and kinetic studies on the adsorption of basic dye by a low-cost adsorbent: Coconut (Cocos nucifera) bunch waste. J. Hazard. Mater. 2008, 158, 65-72. [CrossRef]

49. Johir, M.A.H.; Pradhan, M.; Loganathan, P.; Kandasamy, J.; Vigneswaran, S. Phosphate adsorption from wastewater using zirconium (IV) hydroxide: Kinetics, thermodynamics and membrane filtration adsorption hybrid system studies. J. Environ. Manag. 2016, 167, 167-174. [CrossRef] [PubMed]

50. Yan, K.Z.; Zaini, M.A.A.; Arsad, A.; Nasri, N.S. Rubber seed shell based activated carbon by physical activation for phenol removal. Chem. Eng. Trans. 2019, 72, 151-156.

51. Lavecchia, R.; Medici, F.; Patterer, S.; Zuorro, A. Lead removal from water by adsorption on spent coffee grounds. Chem. Eng. Trans. 2016, 47, 295-300.

52. Amar, I.; Sharif, A.; Ali, M.; Alshareef, S.; Altohami, F.; Abdulqadir, M.; Ahwidi, M.M. Removal of methylene blue from aqueous solutions using nano-magnetic adsorbent based on zinc-doped cobalt ferrite. Chem. Methodol. 2020, 4, 1-18.

53. Regti, A.; Laamari, M.R.; Stiriba, S.-E.; Haddad, M.E. Potential use of activated carbon derived from Persea species under alkaline conditions for removing cationic dye from wastewaters. J. Assoc. Arab. Univ. Basic Appl. Sci. 2017, 24, 10-18. [CrossRef]

54. Koyuncu, H.; Kul, A.R. Removal of aniline from aqueous solution by activated kaolinite: Kinetic, equilibrium and thermodynamic studies. Colloids Surf. A Physicochem. Eng. Asp. 2019, 569, 59-66. [CrossRef]

55. Gokce, Y.; Yaglikci, S.; Yagmur, E.; Banford, A.; Aktas, Z. Adsorption behaviour of high performance activated carbon from demineralised low rank coal (Rawdon) for methylene blue and phenol. J. Environ. Chem. Eng. 2021, 9, 104819. [CrossRef]

56. Tran, T.H.; Le, H.H.; Pham, T.H.; Nguyen, D.T.; La, D.D.; Chang, S.W.; Lee, S.M.; Chung, W.J.; Nguyen, D.D. Comparative study on methylene blue adsorption behavior of coffee husk-derived activated carbon materials prepared using hydrothermal and soaking methods. J. Environ. Chem. Eng. 2021, 9, 105362. [CrossRef]

57. Jiang, L.; Wen, Y.; Zhu, Z.; Liu, X.; Shao, W. A double crosslinked strategy to construct graphene aerogels with highly efficient methylene blue adsorption performance. Chemosphere 2021, 265, 129169. [CrossRef] [PubMed]

58. Theivarasu, C.; Mylsamy, S. Equilibrium and kinetic adsorption studies of Rhodamine-B from aqueous solutions using cocoa (Theobroma cacao) shell as a new adsorbent. Int. J. Engl. Sci. Technol. 2010, 2, 6284-6292.

59. Duraipandian, J.; Rengasamy, T.; Vadivelu, S. Experimental and modeling studies for the removal of crystal violet dye from aqueous solutions using eco-friendly Gracilaria corticata seaweed activated carbon/Zn/Alginate Polymeric composite beads. J. Polym. Environ. 2017, 25, 1062-1071. [CrossRef] 